\title{
HIDRAULIC HAMMER EXCAVATOR FAILURE DUE TO SOLID PARTICLE CONTAMINATION
}

\author{
Mitar T. Jocanović ${ }^{\mathrm{a}}$, Velibor V. Karanović ${ }^{\mathrm{b}}$, \\ Andrea V. Ivanišević ${ }^{a}$, Darko M. Knežević ${ }^{\text {b' }}$ \\ ${ }^{a}$ University of Novi Sad, Faculty of Technical Sciences, \\ Department of Industrial Engineering and Management, \\ ${ }^{\mathrm{b}}$ University of Bania Luka, Faculty of Mechanical Engineering, \\ Department of Automation and Mechanisation, \\ Bosnia and Herzegovina, Republic of Srpska
}

DOI: $10.5937 /$ vojtehg62-4676

FIELD: Mechanical Engineering ARTICLE TYPE: Original Scientific Paper

Summary:

Hydraulic systems of mobile machines are often contaminated by solid particles. Solid particles increase the abrasive wear intensity of hydraulic components and present one of the main causes of system failure. The paper presents a representative example of the solid particle influence on the wear intensity of hydraulic hammer parts, in the cement industry environment.

Ključne reči: particles, excavators, hydraulics, wearing.

\section{Introduction}

Contamination of the working fluid of a hydraulic system is one of

the biggest enemies of mobile machines. In mobile machines that are mostly used in dirty environments, it is necessary to protect the hydraulic system by proper designing, especially in respect of external contamination.

The influence these contaminants have on operation and reliability of hydraulic components and therefore of hydraulic systems as well, may significantly decrease the planned exploitation life (Fitch, 1988), (Biočanin, Pavlović, 2011, pp.106-130), (Guberinić, Milojević, 2009, pp.31-45). Whether their state of matter is gas, liquid or solid, contaminants represent one of the factors that has the biggest impact on failures of hydraulic system components (Liang, et al, 1999, pp.278-298). Solid particles have a significantly destructive character compared to other contaminants (Chandrasekaran, et al, 1985, pp.219-222), (Lehner, Jacobs, 1995, pp.261-276), (Odi-Owei, Roylance, 1986, pp.239-255), (Williams, 
Hyncica, 1992, pp.57-74) and they express it through a mechanism of abrasive and erosive wear (Fitch, Hong, 2004). Solid particles may get into a hydraulic system from the environment in which such a system operates (external contamination) or through internal contamination that is the result of the presence of solid particles in hydraulic fluid (so called "built-in" contamination), or as a result of the wear of operating parts of hydraulic components (Fitch, Hong, 2004).

Problems with using different fluids in hydraulic systems as well as the significance of decreasing the contaminants with regards to proper operation of a hydraulic system have been analyzed through various tests and applied to certain hydraulic components (pumps, valves, etc) (Totten, De Negri, 2011). In addition, the impact of contaminants, in the form of solid particles, on the wear of hydraulic components and systems was monitored through various tests carried out on certain components. It was also proved that solid particles cumulate in clearances of operating components, creating layers of contaminants that may lead to partial or total failure of a hydraulic system component (Jocanović, 2010).

Because of the above mentioned reasons and in order to prevent the increase of total production costs as well as to increase the reliability and efficiency, in modern automatized technological systems it has been insisted on the introduction of system condition monitoring which is the integral part of the preventive and proactive maintenance strategies (Jocanović, et al, 2012, pp.281-288). One should also bear in mind that requests for using the assets, measuring and other equipment needed for carrying out the condition monitoring, need to be valid from the aspect of rentability or, in special circumstances, from the aspect of reliability, regardless of the maintenance expenses and complexity of the technical system (for example military applications and the like).

This paper presents the impact of the contamination of working fluid in the excavator hydraulic system through an operating part - hydraulic hammer. It was noticed that due to the inappropriate design of the hammer and a wrong selection of the return filter in the excavator hydraulic system, during the operation, solid particles as contaminants penetrate inside the hydraulic system and increase the wear of the operating parts of hydraulic components (primarily the operating of the hydraulic pump), as well as the operating parts of the hydraulic hammer. For better understanding of the impact of hydraulic oil contamination with solid particles, this paper also includes a photo-documentation of critical parts of certain components that were damaged. In addition, a financial analysis was also carried out, which justifies the investment in equipment and additional filtering on machines that work in specific conditions. 


\section{Description of the Operation of a Hydraulic Hammer System}

A hydraulic hammer system, shown in Figure 1, receives the working fluid from the pressure line of the central system " $P$ " that is connected with a double piston axial pump with a capacity of $315 \mathrm{l} / \mathrm{min}$. The directional control valve $9 / 3$ (position 1), supplies the hydraulic hammer with the working fluid (position 10) by bringing the control pressure to 1a side of the directional control valve. Through a group of regulating valves (positions 3 and 5) and the pressure line labeled with "I", the oil under pressure supplies the entrance side of the hammer regulating valve (position 10) which further distributes the working fluid according to the phases of hammer operations. The hydraulic accumulator (position 9) decreases the occurrence of hydraulic shocks and pulsations of pressure while the hammer is operating. The oil from the hammer returns directly to the reservoir of the excavator hydraulic system through the return line "O", the directional control valve 7 and the return filter 6 .

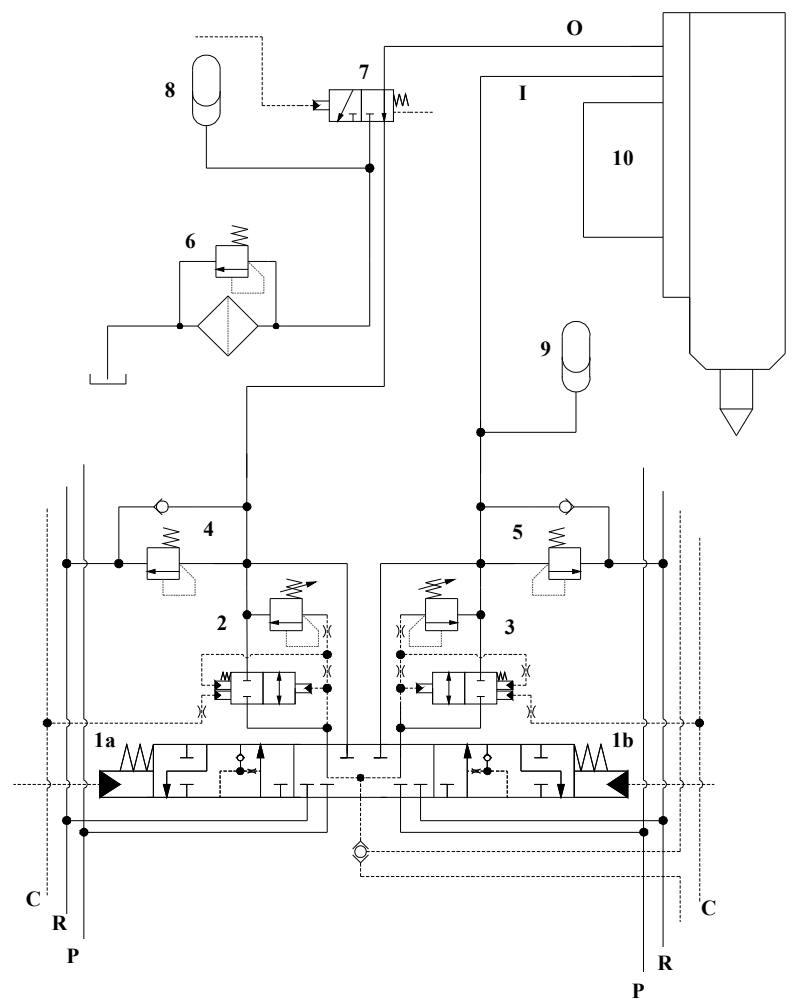

Figure 1-A part of the hydraulic scheme for the operation of the hammer Slika 1 - Posmatrani deo hidraulične šeme čekića 
The cross-sectional view (Figure 2) illustrates the operation of the hydraulic hammer which is performed in phases as follows:

- Phase 1: The working piston $(P)$ moves upwards.

The hydraulic oil from the pressure line enters the chambers labeled by positions 11 and 18 . The regulating valve (19) is pushed into the lower end position. The hammer working piston moves upwards compressing the gas into the compression chamber (15). The working fluid from chamber 14 is released towards the chamber (17) through the hole in the regulating valve (19), and from there, the oil is sent directly to the reservoir through the return line and the filtering system.

- Phase 2: Setting the regulating valve (19) in the upper position.

When the oil under pressure is pushed into the chamber (11), the hammer working piston moves upwards to the position when the chambers (12) and (16) are filled with oil. At the moment when the pressures are equal due to the difference in the surfaces affected by the pressure, the regulating valve (19) moves into the upper end position joining the chambers (18) and (14).

- Phase 3: The working piston moves downwards

When the chambers (14) and (18) are joined, the force which acts on the upper ring-shaped surface of the working piston in the chamber (14) together with the force created by the compressed gas the storage space of the chamber (15) moves the hammer working piston $(P)$ into the lower working position.

- Phase 4: The working piston hits the chisel

When moving downwards, the working piston $(P)$ hits the chisel (20). At that moment, the middle part of the piston joins the chambers (12) and (13) and, as a result, the chamber (16) on the lower side of the regulating valve (19) unloads as well. The force on the lower side of the regulating valve is smaller than on the upper side causing the regulating valve to return to the lower end position.
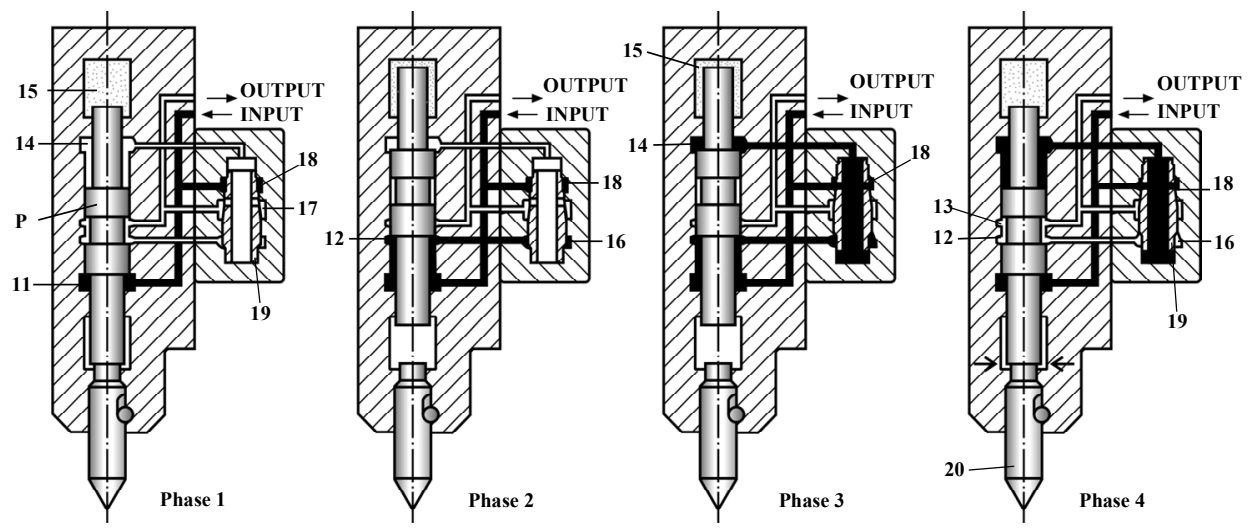

Figure 2 - Crossectional view of the hydraulic hammer and the operational phases Slika 2 - Presek hidrauličnog čekića i njegove radne faze 
The given description presents one operating cycle of the hydraulic hammer. The operating process of causing the hits of the hammer requires continuous repetition of the previously described cycle. From the aforementioned, it can be noticed that the operation of the hydraulic hammer represents a dynamic cycle of movements of certain hammer parts which, in order to work properly, also require certain conditions for long-term exploitation. One of such conditions is also keeping the working fluid clean.

\section{Causes of Contamination in the Excavator Hydraulic System}

In the excavator hydraulic system, it was visually noticed that, due to poor filtering of the filter block (Figure 1 -position 6 ) used in the excavator return line, the color of the hydraulic oil changes due to the presence of solid particles of cement dust, which affects the work and reliability of the excavator during the exploitation. Frequent failures of certain components in the system were noticed (of proportional and servo type). In order to prove the assumption relating to inadequate filtering, oil samples were taken from the reservoir (a reservoir volume of 250 liters) of the hydraulic excavator that had been exploited for 950 work hours. By imaging the content of solid particles in oil mass with a device type FCU 2045 HYDAC (Hydac International $\mathrm{GmbH}$., 2010), we obtained the information about the oil purity class (Table 1 ).

By monitoring the contamination with solid particles, it is crucial to define the sources of contamination, and later, to spot and correct possible mistakes which cause contamination. When the filtering in the system is not appropriate, it generally leads to a constant increase of contaminants in the form of solid particles in the working fluid of the hydraulic system. In the case of an excavator, there were three basic causes of contamination of the working fluid.

Table 1 - Content of solid particles in the oil mass of the excavator hydraulic system Tabela 1 - Sadržaj čvrstih čestica u uljnoj masi hidrauličnog sistema bagera

\begin{tabular}{|c|c|c|c|c|c|c|c|c|}
\hline $\begin{array}{c}\text { Description } \\
\text { and the } \\
\text { number of } \\
\text { the sample }\end{array}$ & \multicolumn{2}{|c|}{$\begin{array}{c}\text { Number of } \\
\text { operating hours [h] }\end{array}$} & \multicolumn{2}{c|}{$\begin{array}{c}\text { Number of measured solid particles } \\
\text { by size in the } 100 \mathrm{ml} \text { sample }\end{array}$} & \multicolumn{2}{c|}{ Purity class } \\
\cline { 2 - 9 } & excavator & oil & $2 \mu \mathrm{m}$ & $5 \mu \mathrm{m}$ & $15 \mu \mathrm{m}$ & $25 \mu \mathrm{m}$ & $\begin{array}{c}\text { NAS } \\
1638\end{array}$ & ISO4406/88 \\
\hline $\begin{array}{c}\text { Before } \\
\text { filtering (1) }\end{array}$ & 950 & 950 & $>>>$ & $8,585.215$ & $1,605.631$ & $1,327.103$ & $>15$ & $24 / 23 / 21$ \\
\hline
\end{tabular}

> > - too many particles immeasurable by the device 
The executive part of the excavator hydraulic system, i.e. the hammer, was noticed as the first source of contamination (of an external character) during the monitoring process. Through the operating parts of the hammer, due to a mistake in the design (a poor sealing system), there is a penetration of a big quantity of solid particles washed down by the working fluid and distributed in the hydraulic system through the return line into the reservoir of the working fluid.

The second source of contamination (of an internal character) is the inadequate solution for filtering the working fluid in the return line of the hydraulic hammer system. With regards to the filter construction, the degree of the filtration rate is $\beta_{x}=200$ for $30 \mu \mathrm{m}$ particles. However, the system has a built-in axial piston pump with the LS regulation and the group of proportional and servo valves for the operation of which one needs to provide filters with a degree of fineness between 2 and $5 \mu \mathrm{m}$ in line with the old ISO $4406 / 87$, or 4 and $6 \mu \mathrm{m}(\mathrm{c})$ in line with the new ISO 4406/99 standard.

The third cause of contamination is the inadequately designed system of the hammer return line, especially the filter block (Figure 1 - position 6). During the monitoring process, it was noticed that there were some sudden rises of pressure in the filter housing which causes the tearing of the steel filter mesh (Figures 3 and 4 ) and the penetration of filth in the form of solid particles.

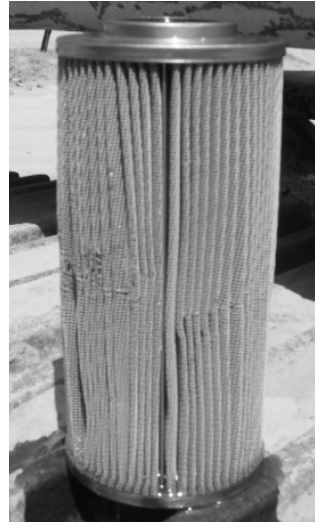

Figure 3 - Filter cartridge embedded in the return line of the hydraulic hammer system Slika 3 - Filterski uložak, ugrađen u povratnom vodu hidrauličnog sistema čekića

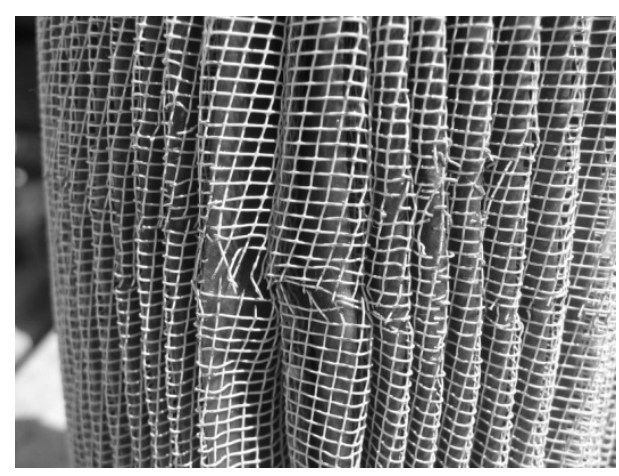

Figure 4 - Visible damage in the steel mesh and the filter medium

Slika 4 - Vidljiva oštećenja na čeličnoj mrežici filterskog uloška

In order to prove the previously mentioned facts, the contamination of the new fluid was measured before the system was put into operation and after a certain period of exploitation, and the measuring results are presented in Table 2. We also need to mention that filtering was executed with external, i.e. a secondary filtering system, and that the samples were taken from the reservoir in line with the prescribed sampling method. 
Table 2 - Results of measuring solid particles in the excavator working fluid mass after oil change

Tabela 2 - Rezultati merenja čvrstih čestica u hidrauličnom sistemu bagera nakon zamene ulja

\begin{tabular}{|c|c|c|c|c|c|c|c|c|}
\hline \multirow{2}{*}{$\begin{array}{l}\text { Description } \\
\text { and the } \\
\text { number of } \\
\text { the sample }\end{array}$} & \multicolumn{2}{|c|}{\begin{tabular}{|c|} 
Number of \\
operating hours \\
[h]
\end{tabular}} & \multicolumn{4}{|c|}{$\begin{array}{l}\text { Number of measured solid particles by } \\
\text { size in the } 100 \mathrm{ml} \text { sample }\end{array}$} & \multicolumn{2}{|c|}{ Purity class } \\
\hline & $\begin{array}{l}\text { Exca- } \\
\text { vator }\end{array}$ & New oil & $2 \mu \mathrm{m}$ & $5 \mu \mathrm{m}$ & $15 \mu \mathrm{m}$ & $20 \mu \mathrm{m}$ & $\begin{array}{l}\text { NAS } \\
1638\end{array}$ & $\begin{array}{c}\text { ISO } \\
4408 / 87\end{array}$ \\
\hline \begin{tabular}{|c|} 
After filtering \\
the new \\
oil (2) \\
\end{tabular} & 950 & 0 & 168.887 & 16.767 & 112 & 49 & 7 & $18 / 16 / 10$ \\
\hline \begin{tabular}{|c|} 
During the \\
operation (3)
\end{tabular} & 985 & 35 & 2.752 .511 & 163.839 & 2.159 & 1.847 & 10 & $21 / 18 / 13$ \\
\hline $\begin{array}{c}\text { During the } \\
\text { operation (4) }\end{array}$ & 1230 & 280 & 4.227 .071 & 1.261 .567 & 34.047 & 37.375 & 13 & $23 / 21 / 17$ \\
\hline
\end{tabular}

As it can be noticed, the content of contaminants in the form of solid particles in the working fluid increased from satisfying purity class NAS 7 to unpermitted class NAS 10 for a very short period of operating time (35 hours) of the excavator in the extremely contaminated environment (cement industry environment). After 280 operating hours, the oil purity class increased to NAS 13 which represented a class of contamination at unpermitted level (Figure 5).

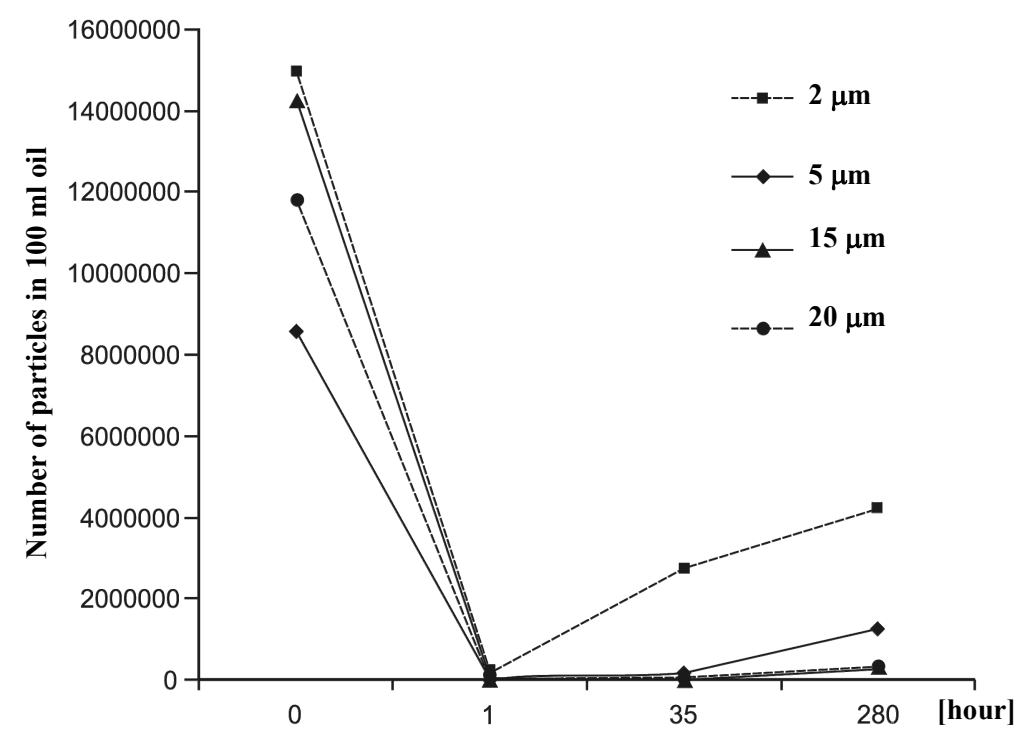

Figure $5-$ Increase in the oil contamination level in 280 operating hours Slika 5 - Povećanje kontaminacije ulja za 280 radnih časova 
Since the excavator was within the warranty period, there was not any possibility to make any change on the hydraulic excavator system in agreement with the servicing staff. The servicing staff insisted that both oil and filters were supposed to be replaced even before the prescribed terms (prescribed replacement of filters after 1000 hours; changing oil after 5000 operating hours), ignoring the presented observations and reports relating to the operation and contamination of the working fluid in the hydraulic excavator system. It is also important to mention that during 1230 hours of the excavator operation, there were three replacements of filters in the hammer return line and one complete change of oil at 950 working hours.

\section{Influence of Contaminants on the Damage of Hydraulic Excavator Components}

Research on the negative impact of contaminants in the form of solid particles was done on a new excavator the exploitation life of which ended after only 1230 operating hours. Because of the inadequately designed hydraulic system, as well as due to a mistake in the design of the excavator hammer, the penetration of contaminants (particles originating from $\mathrm{SiO}_{2}, \mathrm{MgO}, \mathrm{CaO}_{3}$, $\mathrm{Al}_{2} \mathrm{O}_{3}$ ) into the hydraulic system was at a very high level. The role of the filter in the system may be neglected because the filter did not do the work which, according to the system functioning plans, it was supposed to do.

Due to a poor design of the hammer sealing system, where there is only one seal for dust removal (Figure 6 - position 47), a great quantity of solid particles from the atmosphere of the cement industry work environment penetrated the housing of the hammer (Figure 6 - position 1). Solid particles that penetrated the interior of the hammer were washed down by the working fluid and sent to other parts of the hydraulic system, all the way to the reservoir, and after that the pump sent them again to the executive part and other components of the excavator hydraulic system. In this way, the level of contamination cyclically increased in the working fluid.

Due to the penetration of solid particles into the housing, damage occurred in the form of metal particles, as in Figure 7 which presents the interior of the hammer housing (Figure 6 - position 1) with the products of wear that occurred as a result of primarily abrasive wear and partially due to vibration. Figure 8 shows an enlarged image of the housing with the presence of particles and Figure 9 shows the assembly of the piston and the housing with the presence of accumulated solid particles after disassembling the hydraulic hammer. In the presented housing (Figure 9), there is a driving part of the hammer piston (Figure 6 - position 12) which is also presented in Figure 10 with visible traces of abrasive wear resulting from the performance of solid particles from the environment. Due to 
the presence of contaminants, significant damage is visible on the hammer piston in the form of longitudinal scratches that occurred as a result of the abrasive impact of solid particles present in the oil and vibrations that occurred during the operation of the hammer.

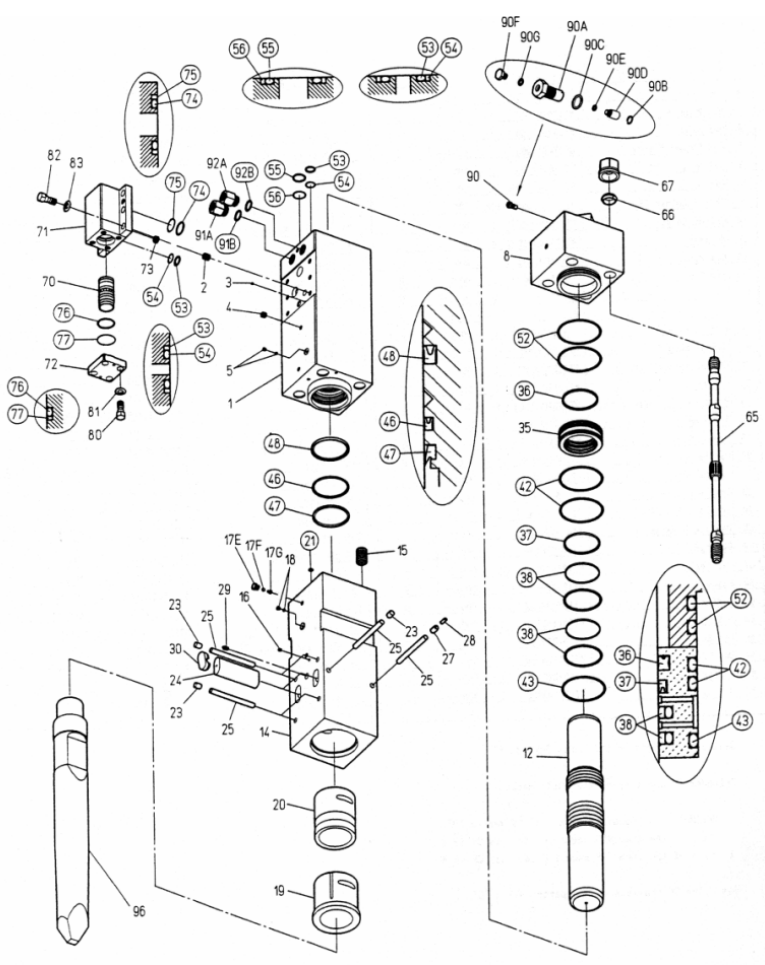

Figure 6 - Explosion scheme of the hydraulic hammer Slika 6 - Detaljna šema hidrauličnog čekića

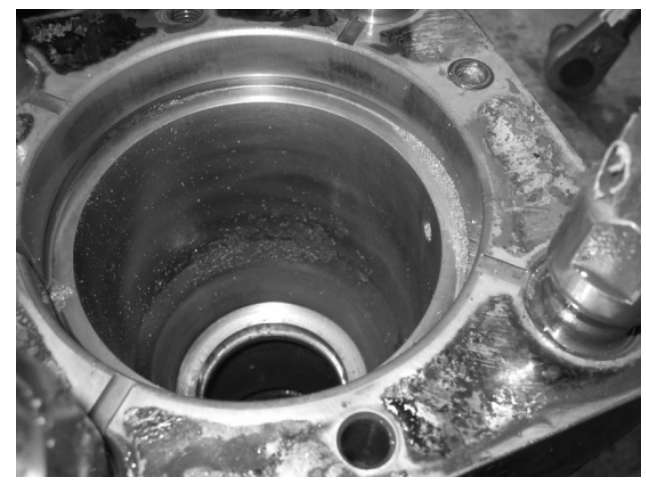

Figure 7 - Housing of the hammer with particles Slika 7 - Kućište čekića sa vidljivim čvrstim česticama 


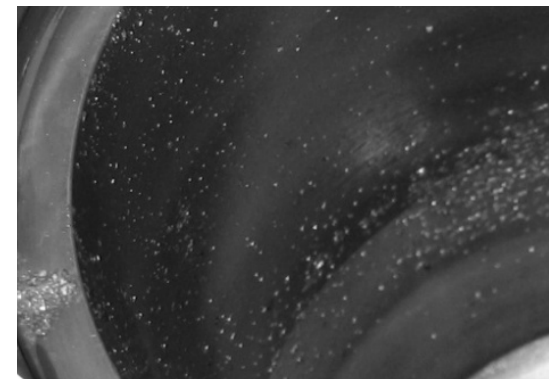

Figure 9 - The assembly of the housing and the piston of the hammer with solid

Slika 9 - Sklop kućišta i klipa hidrauličnog čekića sa vidljivim čvrstim česticama

Slika 9 - Sklop kućišta i klipa hidrauličnog čekića sa vidljivim čvrstim česticama

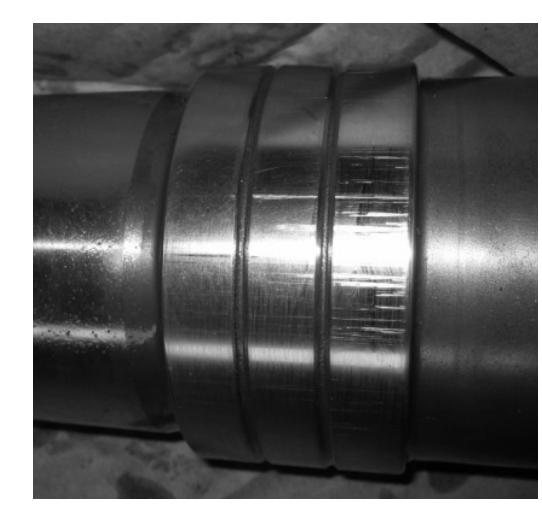

\section{Slika 8 - Uvećan prikaz kućišta sa metalnim česticama}

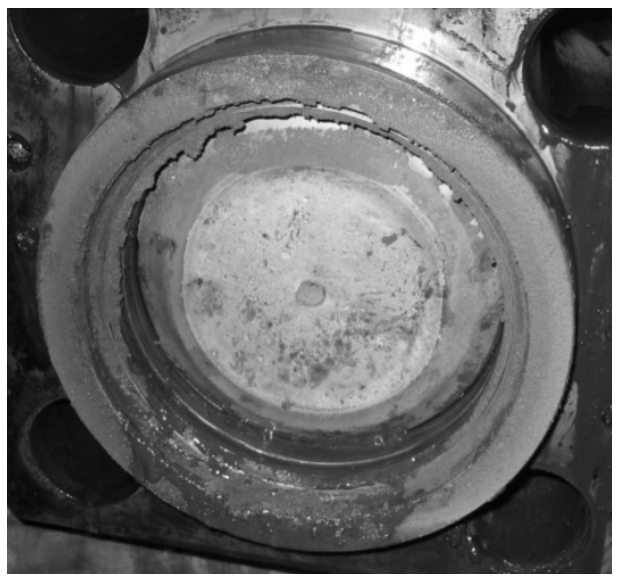

Figure 10 - Abrasive damage on the hammer piston Slika 10 - Abrazivna oštećenja na klipu čekića 
Solid particles present in the working fluid also caused the abrasive wear damage on the piston of the hammer regulating valve (Figure 6 - position 70) and it is shown in Figure 11.

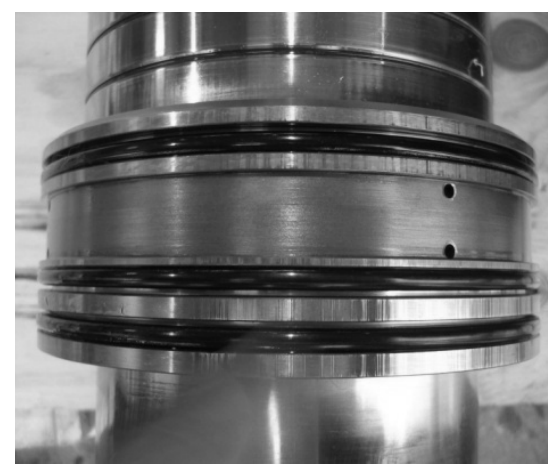

Figure 11 - Abrasive damage of the regulating valve piston Slika 11 - Abrazivna oštećenja na klipu regulacionog ventila

Besides the presented parts of only one operating assembly of the hydraulic hammer system, the hydraulic excavator system also had damage on other components, primarily on the axial piston pumps with the LS regulation as well as on the proportional control valves. On the basis of the detailed analyses of the damage causes, on the filter and other hydraulic components, we came up with an idea to use the equipment for monitoring the basic physical values (pressure, flow and temperature) in the return line and, based on these values, to state the cause of the mechanical failure of the filter cartridge.

\section{Monitoring the Hydraulic Hammer System}

In the hydraulic hammer system, on the return line that takes the oil out of the hammer housing through the filter block (Figure 1 - position 6), the sensors for measuring the pressure (Figure 12) were set up on the measuring points $M 1$ and M2. Based on the measured values obtained through the multy handy diagnostic unit 2045 (Hydrotechnik UK, 2012), it was determined that when the hammer chambers 12,13 and 16 were unloaded in phase 4 (Figure 2), the pressure dropped in the return line between the inlet (M2) and the outlet (M1) of the filter housing, to the value of $\Delta p=3.5$ bars (Figure 13). According to the manufacturer's recommendation, the pressure relief valve embedded in the housing of the filter was adjusted to open after the pressure had reached the value of $\Delta p \max =1.5$ bars. Due to the impact of variable pressure values of $\Delta p=3.5$ bars on the filter cartridge, or more specifically on the mesh and the filtering medium, 
enormous force was generated leading to bending and twisting of the medium and steel protection of the filter cartridge. Due to the cyclic loading, the steel mesh became worn out and torn and the filter cartridge medium was splitted (Figures 3 and 4). This phenomenon was also identified after replacing the old filter cartridge with a new one. After only 250 operating hours, the same phenomenon and the damage happened again. Due to mechanical damage, the filter cartridge no longer performed its role and the contaminants that passed through clearances between the seals and the working piston went directly into the reservoir of the hydraulic system.

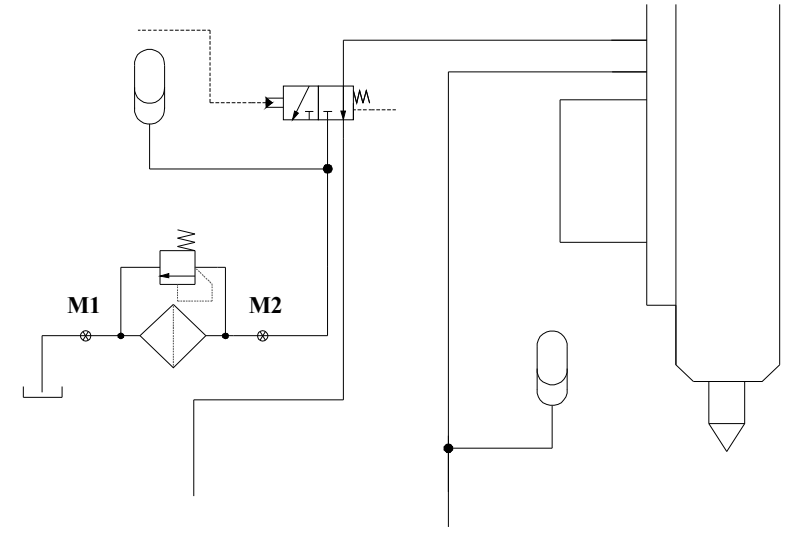

Figure 12 - Measuring points in the filter block of the hydraulic hammer system return line Slika 12 - Merna mesta na filterskom bloku u povratnom cevovodu hidrauličnog sistema

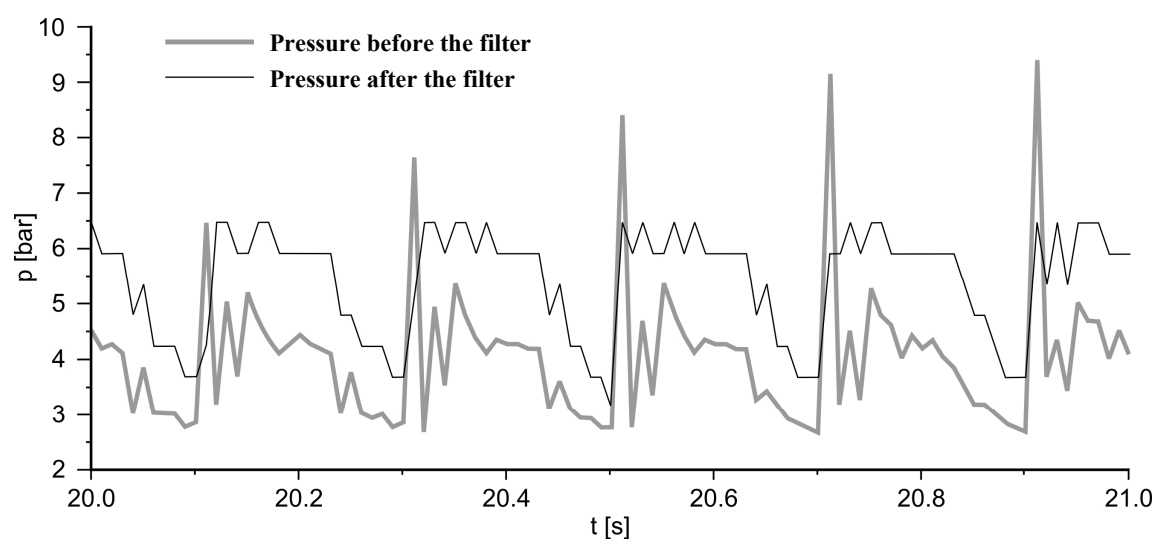

Figure 13 - Changes of pressure values in the filter block of the hammer return line Slika 13 - Izmerene promene pritiska na filterskom bloku

After the monitoring process, the main cause of damage in the filter cartridge was determined and after that the source of contamination of the whole system was determined as well. 
The solution to the problem was achieved in agreement with the excavator supplier who performed an adequate replacement of damaged components in the hydraulic system and fixed the defect in the hammer return line filter block by installing a filter with appropriate fineness of 4 $\mu \mathrm{m}(\mathrm{c})$ and by setting the pressure relief valve in the filter block to the value of 1.5 bars. In addition, the hammer was replaced with another hammer with an appropriate structural design with an improved sealing system that prevented the excessive penetration of solid particles into the interior of the hammer. Also, a secondary filtering system was installed on the main reservoir of the hydraulic excavator system, with the capacity of $10 \%$ of the capacity of the main hydraulic pumps. A permanent solution was thus provided for additional filtering of the hydraulic working fluid and for keeping its pureness at the required level.

\section{Techno-financial Analysis of the Breakdown}

Due to the breakdown that occurred in the hydraulic system, the main cause of which was the excessive contamination with solid particles and improper filtration, the user of the excavator filed a claim for a replacement of components in the whole hydraulic excavator system. In negotiations with the manufacturer, after submitting adequate evidence, an agreement was reached to do so. Table 3 shows the costs of the new hydraulic hammer and the replaced hydraulic excavator system without executive elements (hydraulic cylinders were not replaced), as well as the costs of the secondary filtering system with a counter of solid particles and a sensor for measuring moisture in the oil mass that may timely signalize the operator when the level of contamination with solid particles in the system increases so that he/she may respond in time. Normally, the secondary system does not have to be connected to the hydraulic system all the time; it is used from time to time, for a certain number of operating hours, in order to separate the contaminants in the form of water and particularly solid particles.

Table 3 - The price of the equipment installed in the hydraulic excavator system Tabela 3 - Cena opreme ugrađene u hidraulični sistem bagera

\begin{tabular}{|l|l|l|r|}
\hline No. & Component type & Quantity & Costs (EUR) \\
\hline 1. & $\begin{array}{l}\text { Hydraulic blocks with a set of regulating valves } \\
\text { for controlling the power employed for movement, } \\
\text { rotation and operation of the excavator arm }\end{array}$ & 5 blocks & $128,412.00$ \\
\hline 2. & Set of two axial piston pumps with the LS regulation & 2 pieces & $15,560.00$ \\
\hline 3. & $\begin{array}{l}\text { Hydraulic drive motors for movement and rotation } \\
\text { with the associated regulating valves in the block }\end{array}$ & 3 pieces & $24,954.00$ \\
\hline 4. & Hydraulic hammer & 1 piece & $29,530.00$ \\
\hline & \multicolumn{2}{|l}{ TOTAL: } & $198,456.00$ \\
\hline
\end{tabular}




\begin{tabular}{|l|l|l|r|}
\hline No. & Component type & Quantity & Costs (EUR) \\
\hline 1. & $\begin{array}{l}\text { Secondary filtering system with two filters of big } \\
\text { capacity (pump capacity 25 liters/minute } \\
\text { and filtration rating } \beta_{\mathrm{x}}=200 \text { size } 14 \text { and } 4 \mu \mathrm{m}(\mathrm{c}) .\end{array}$ & 1 piece & $2,875.00$ \\
\hline 2. & $\begin{array}{l}\text { Device for measuring solid particles } \\
\text { and the moisture sensor }\end{array}$ & 1 piece & $4,870.00$ \\
\hline 3. & Price of the spare filter 14 or $4 \mu \mathrm{m}(\mathrm{c})$. & 1 piece & 200 \\
\hline & & TOTAL: & $7,945.00$ \\
\hline
\end{tabular}

Table 4 presents the financial analysis of all expenses relating to the breakdown, maintenance and repair of the excavator as well as the ratio of losses of the excavator owner and manufacturer.

Table 4 - The Cost analysis review Tabela 4 - Analiza troškova

\begin{tabular}{|c|c|c|c|c|}
\hline & & $\begin{array}{l}\text { Calculation } \\
\text { element }\end{array}$ & $\begin{array}{l}\text { Amount } \\
\text { (EUR) }\end{array}$ & Note \\
\hline \multicolumn{5}{|c|}{ Basic income parts of the excavator operation } \\
\hline 1. & $\begin{array}{l}\text { Total cost of the excavator } \\
\text { with a hammer }\end{array}$ & & $550.000,00$ & \\
\hline 2. & $\begin{array}{l}\text { Annual income of the } \\
\text { excavator with full } \\
\text { operating hours }\end{array}$ & $\begin{array}{l}\text { Number of } \\
\text { operating hours: } \\
\text { around } 2000 \\
\text { Cost of excavator } \\
\text { operating hour: } \\
110 \text { EU }\end{array}$ & $210.000,00$ & $\begin{array}{l}\text { Operating hour cost } \\
\text { comprises the fol- } \\
\text { lowing expenses: } \\
\text { amortization and } \\
\text { loan, work force, } \\
\text { energy substances, } \\
\text { servicing, admini- } \\
\text { stration costs, } \\
\text { insurance, com- } \\
\text { pany's profit }\end{array}$ \\
\hline 3. & Annual profit assessment & $10 \%$ of profit & $21.000,00$ & \\
\hline \multicolumn{5}{|c|}{ Loss review } \\
\hline 1. & $\begin{array}{l}\text { Lost income during the } \\
\text { litigation (IP) }\end{array}$ & 4 months & $70.000,00$ & \multirow[t]{3}{*}{$\begin{array}{l}4 \text { month long } \\
\text { litigation }\end{array}$} \\
\hline 2. & $\begin{array}{l}\text { Lost profit during the } \\
\text { litigation (ID) }\end{array}$ & 4 months & $7.000,00$ & \\
\hline 3. & $\begin{array}{l}\text { Work force costs during the } \\
\text { litigation (TR) }\end{array}$ & 4 months & $6.000,00$ & \\
\hline 4. & $\begin{array}{l}\text { Cost of replaced parts due } \\
\text { to wear caused by oil } \\
\text { contamination (TI) } \\
\end{array}$ & & $198.456,00$ & $\begin{array}{l}\text { Manufacturer } \\
\text { covered the costs }\end{array}$ \\
\hline 5. & $\begin{array}{l}\text { Cost of upgrading the filter- } \\
\text { ing system (TF) }\end{array}$ & & $7.945,00$ & $\begin{array}{l}\text { Manufacturer } \\
\text { covered the costs }\end{array}$ \\
\hline 6. & $\begin{array}{l}\text { Litigation expenses } \\
\text { (oil change, examination, } \\
\text { servicing the hammer and the } \\
\text { excavator, expert's opinion) } \\
\text { (OT) }\end{array}$ & & $30.000,00$ & $\begin{array}{l}\text { Manufacturer and } \\
\text { user shared the } \\
\text { expenses fifty-fifty. }\end{array}$ \\
\hline \multicolumn{5}{|c|}{ SUMMARY } \\
\hline A & User's loss & $\mathrm{TI}+\mathrm{TF}+0,5 \cdot \mathrm{OT}$ & $221.401,00$ & \\
\hline $\mathrm{B}$ & Manufacturer's loss & $\mathrm{ID}+\mathrm{TR}+0,5 \cdot \mathrm{OT}$ & $28.000,00$ & \\
\hline
\end{tabular}


In the table above, one may see that for the equipment which keeps the contamination level in the hydraulic system at the needed level, it was necessary to allocate only $4 \%$ of the total amount that was needed to bring the excavator to the proper operating condition. Since this is a negligible amount compared to the total value of the excavator, the general conclusion in this analysis would be that for the assets invested in the secondary filtering system that should maintain the level of oil cleanliness at a required level, far more is returned through reliability and efficiency of the excavator during the operation. The best indicator that the application of diagnostics and the system for keeping the level of contamination at a required level is done properly is the fact that during the exploitation of 4500 operating hours the excavator operated without any failures after the replacement of its hydraulic components.

\section{Conclusion}

A proper application of diagnostics and appropriate maintenance of the hydraulic system led to the conclusions as follows:

- By applying diagnostics to certain operating parameters of the hydraulic system (such as pressure, flow, fluid operating temperature, temperature of critical components, etc.) and by monitoring the contamination level, it is possible to determine the cause of failures or failures of certain parts in the hydraulic system or the whole system. In addition, with a proper use of certain diagnostic devices, and by knowing the critical points in the system, the system parts and components working under the largest loads can be identified, as well as the values of certain operating parameters that may lead to a failure of a component,

- By constantly monitoring the operating parameters in the hydraulic system and a level of contamination through automatic control, it is possible to forecast adequately and act preventively in order to remove the potential causes of system failure,

By an appropriate replacement and a proper choice of critical parts in the hydraulic system, the overall reliability of the hydraulic system is upgraded as well as the productivity and efficiency of the system,

- With minimum investments in corresponding equipment for keeping the contamination level in the hydraulic system, multiple expenses of hydraulic system maintenance are decreased, providing a proper and long-lasting operation of the hydraulic system.

In conclusion, it can be said that for maintaining a hydraulic system it is necessary to apply certain diagnostic measures during the operation of a modern hydraulic system, as well as appropriate systems for keeping the pureness of the working fluid at the level required for pro- 
per operation of the system. The symbiosis between diagnostics and devices for controlling the working fluids, especially hydraulic oils, has been lately recognized as unavoidable and it requires the increasing application and installation of these devices as standard parts in modern machines.

\section{Literatura}

Biočanin, S., \& Pavlović, M. 2011. Determining the optimal periodicity of the V46-6 engine preventive maintenance. Vojnotehnički glasnik/Military Technical Courier, 59(3), pp. 106-130. doi:10.5937/vojtehg1103106

Chandrasekaran, S., Khemchandani, M.V., \& Sharma, J.P. 1985. Effect of Abrasive Contaminants on Scuffing. Tribology International, 18(3), pp. 219-222.

Fitch, E.C. 1988. Fluid contamination control.Stillwater, OK, USA: FES Inc..

Fitch, E.C., \& Hong, I.T. 2004. Hydraulic System Design for Service Assurance.Stillwater, Oklahoma, USA: Bar Dyne Inc.

Guberinić, R., \& Milojević, I. 2009. Određivanje funkcije pouzdanosti motornih vozila kao složenog tehničkog sistema. Vojnotehnički glasnik/Military Technical Courier, 57(2), pp. 31-45.

Hydac International GmbH. Fluid Control Unit FCU 2000 Series Catalogue 2010. Germany: Hydac International GmbH..

Hydrotechnik UK. 2012. Industrial test \& measurement equipment - Product Catalogue.United Kingdom: Hydrotechnik UK.

Jocanovic, M. 2010. Approach to Research and Define the Model for the Calculation of Flow of Solid Particles with a Mass of Mineral Oil through the Gaps in a Function of the Constructive Operating Parameters of Hydraulic Components. University of Novi Sad.

Jocanović, M., Šević, D., Karanović, V., Beker, I., \& Dudić, S. 2012. Increased Efficiency of Hydraulic Systems Through Reliability Theory and Monitoring of System Operating Parameters. Strojniški vestnik-Journal of Mechanical Engineering, 58(4), pp. 281-288. doi:10.5545/sv-jme.2011.084

Lehner, S., \& Jacobs, G. 1995. Contamination Sensitivity of Hydraulic Pumps and Valves. . In: Proceedings of Tribology of Hydraulic Pump Testing, USA, December 4-5. , pp. 261-276

Liang, H., Mizuno, K., Totten, G.E., \& Bishop, R.J. 1999. Fundamental Hydraulic Wear Processes. In: Proceedings of Hydraulic Failure Analysis: Fluids, Components, and System Effects, Reno, December 5-6. , pp. 278-298

Odi-Owei, S., \& Roylance, B.J. 1986. The Effect of Solid Contamination on the Wear and Critical Failure Load in a Sliding Lubricated Contact. Wear, 112(3), pp. 239-255.

Totten, G.E., \& de Negri, V.J. 2011. Handbook of hydraulic fluid technology.USA: CRC Press.

Williams, J.A., \& Hyncica, A.M. 1992. Mechanisms of Abrasive Wear in Lubricated Contacts. Wear, 152(1), pp. 57-74. 


\section{OTKAZ HIDRAULIČNOG SISTEMA ČEKIĆA KAO POSLEDICA KONTAMINACIJE ČVRSTIM ČESTICAMA}

OBLAST: mašinstvo

TIP ČLANKA: originalni naučni članak

\section{Rezime:}

Hidraulični sistemi mobilnih mašina su često kontaminirani čvrstim česticama. Čvrste čestice povećavaju intenzitet abrazivnog habanja hidrauličnih komponenata, i čine jednim od glavnih uzročnika otkaza sistema. $U$ radu je dat prikaz reprezentativnog primera uticaja čvrstih čestica na povećano habanje delova hidrauličnog čekića bagera u eksploatacionim uslovima bagera u cementnoj industriji.

Uvod

Kontaminacija radnog fluida hidrauličnog sistema, jedan je od najvećih neprijatelja mobilnih mašina. Na mobilnim mašinama, koje se obično koriste u kontaminiranoj sredini, potrebno je pravilnim projektovanjem zaštititi hidraulični sistem posebno od eksterne kontaminacije. Uticaj kontaminanata na rad i pouzdanost hidrauličnih komponenata, a time i hidrauličnih sistema, može značajno da smanji planirani eksploatacioni vek.

$U$ radu je dat prikaz uticaja kontaminacije radnog fluida hidrauličnog sistema bagera preko radnog dela, hidrauličnog čekića. Uočeno je da zbog loše konstrukcije čekića i nepravilnog izbora povratnog filtera $u$ hidrauličnom sistemu bagera, u toku rada dolazi do prodora kontaminanata u vidu čvrstih čestica koje dovode do povećanja habanja radnih delova hidrauličnih komponenata (prvenstveno pogonske hidraulične pumpe) kao i radnih delova hidrauličnog čekića. Da bi se shvatio uticaj kontaminacije hidrauličnog ulja čvrstim česticama, u radu je priložena foto-dokumentacija kritičnih delova pojedinih komponenti koje su oštećene. Takođe, izvršena je ekonomska analiza koja ukazuje na potrebu da se na mobilnim mašinama izvrši adekvatno filtriranje hidrauličnog fluida.

Opis rada hidrauličnog sistema čekića

Dat je opis jednog radnog ciklusa hidrauličnog čekića. Radni proces izazivanja udaraca čekićem zahteva kontinualno ponavljanje prethodno opisanog ciklusa. Iz navedenog se vidi da je rad hidrauličnog čekića veoma dinamičan ciklus kretanja određenih delova čekića, koji da bi ispravno radili zahtevaju i određene uslove za dugotrajnu ekspolataciju. Jedan od tih uslova je i održavanje radnog fluida čistim.

Uzročnici kontaminacije na hidrauličnom sistemu bagera

Priložena fotodokumentacija daje prikaz jednog od glavnih uzročnika povećane koncentracije kontaminanat u fluidu - neispravan filterski uložak, koji se usled cikličnih opterećenja habao i nije vršio zadatu funkciju. 
Uticaj kontaminanata na oštećenje hidrauličnih komponenata bagera

Na priloženim slikama uočavaju se tragovi abrazivnog habanja kao glavne vrste trošenja radnih elemenat hidrauličnog čekića, koji su nastali kao posledica prodora ogromne količine kontaminanata u vidu čvrstih čestica cementne i betonske prašine u hidraulični sistem bagera.

Monitoring hidrauličnog sistema čekića

$U$ hidrauličnom sistemu bagera i radnog sklopa - hidrauličnog čekića, uz pomoć uređaja za snimanje čvrstih čestica u radnom fluidu, otkriveni su glavni uzročnici kontaminacije koji su dovodili do relativno brzog zastoja hidrauličnog sistema i čekića.

Tehno ekonomska analiza nastale havarije

Iz izvedene analize se vidi da je za opremu kojom se održava nivo kontaminacije u hidrauličnom sistemu na potrebnom nivou neophodno izdvojiti svega 4\% od ukupne sume koja je bila potrebna da se bager dovede $u$ ispravno stanje. Kako je ovo zanemariva cifra u odnosu na ukupnu vrednost bagera, opšti zaključak u ovoj analizi je da se za uložena sredstva u sekundarni sistem filtriranja kojim se postiže nivo održavanja uljnog punjenja na potrebnom nivou, daleko više vraća kroz pouzdanost i efikasnost bagera u toku rada.

Zaključak

Pravilna primena dijagnostike i odgovarajuće održavanje hidrauličnog sistema ukazuje na sledeće zaključke:

- Određenim dijagnostičkim uređajima i njihovom pravilnom primenom i poznavanjem kritičnih tačaka u sistemu mogu se utvrditi delovi $i$ komponente u sistemu koji podnose najveća opterećenja kao i vrednosti određenih radnih parametara koji mogu dovesti do zastoja ili otkaza komponente,

- stalnim praćenjem radnih parametara u hidrauličnom sistemu $i$ nivoa kontaminacije putem automatske kontrole, moguće je na adekvatan način predvideti i preventivno delovati kako bi se otklonile potencijalni uzroci otkaza sistema,

- odgovarajućom zamenom i pravilnim izborom kritičnih delova u hidrauličkom sistemu, povisuje se ukupna pouzdanost hidrauličnog sistema kao i produktivnost i efikasnost sistema,

- uz minimalna ulaganja u odgovarajuću opremu za održavanje nivoa kontaminacije u hidrauličnom sistemu, smanjuju se višestruki troškovi održavanja hidrauličnog sistema i obezbeđuje pravilan i dugotrajan rad hidrauličnog sistema.

Ključne reči: čvrste čestice, bageri, hidraulika, habanja.

Datum prijema članka/Paper received on: 16. 10. 2013.

Datum dostavljanja ispravki rukopisa/Manuscript corrections submitted on: 02. 11. 2013.

Datum konačnog prihvatanja članka za objavljivanje/ Paper accepted for publishing on:

04. 11. 2013. 